\title{
The Impact of Economic Value Added, Market Value Added and Traditional Accounting Measures on Shareholders' Value: Evidence from Jordanian Commercial Banks
}

\author{
Hanan Ali Al-Awawdeh ${ }^{1} \&$ Sa'ad Abdul Kareem Al-Sakini ${ }^{1}$ \\ ${ }^{1}$ Isra University, Jordan \\ Correspondence: Hanan Ali Al-Awawdeh, Assistant Professor, Isra University, Jordan.
}

Received: August 6, 2018

Accepted: August 25, 2018

Online Published: September 15, 2018

doi:10.5539/ijef.v10n10p40

URL: https://doi.org/10.5539/ijef.v10n10p40

\begin{abstract}
The purpose of this is study is to test the impact of economic value added, market value added and traditional accounting measures on the shareholders' value in the Jordanian commercial banks, based on a sample of 13 banks during the period 2010-2016.

The study used the shareholders' value as a dependent variable, while five independent variables were used, including Economic Value Added (EVA), Market value added (MVA), and three traditional accounting measures, namely; the rate of return on assets (ROA), rate of return on equity (ROE), and the Earning per share (EPS).

The study found, by using the common regression analysis, that the rate of return on assets (ROA) and the economic value added (EVA) had a positive and statistically significant effect on maximizing the shareholders' value, while the rest of the traditional accounting standards or the market added value had no any significant impact on shareholder' value.

The study concluded that traditional accounting standards are still constitute an important input for assessing shares, and maximizing the shareholders' value along with modern performance assessment measures, especially economic value added. The study recommended that the performance assessment of banks should be based on two criteria: the rate of return on assets and the economic value added.
\end{abstract}

Keywords: traditional accounting measures, economic added value, market added value, shareholders' value

\section{Introduction}

Public shareholding companies seek to maximize the shareholders' value through maximizing the market value of the share, which is important in order to ensure the company's ability to achieve its economic survival. If the company's management is unable to achieve this goal, it may cause failure and collapse (Panigrahi et al., 2014).

Although the relationship between performance measures and the shareholders' value has been extensively debated in the accounting literature, such literature has not been able for long periods to identify the appropriate performance measurement tool that can be linked to the shareholders' value. The published financial statements remained unable to determine the real value of the company, which prompted many researchers to focus on the gap between the market value and the book value of the Company (Othman et al., 2012).

The accounting performance indicators had a broad interest from researchers. These indicators have significant developments over time, and a clear shift from the focus on accounting revenue and profits as performance indicators to the focus on indicators that avoid criticism of profits and revenue; such as rate of return on assets, rate of return on equity, and other accounting performance indicators (Alkhalialeh, 2004).

As the debate continues over the adequacy and appropriateness of traditional accounting measures, such as Earning per share (EPS), return on assets (ROA), and return on equity (ROE), due to the criticisms of these indicators, especially in terms of their effects on the market value of shares, and its failure to reflect the real value of the company (Vijayalakshmi, 2014), and its relying on the estimates in the measurement of accounting profits, and its impact on different accounting methods, a trend has emerged for the use of new performance indicators. The most important among these new indicators is the economic value added (EVA), which has been developed by an American consulting firm called (Sternand Stewart Co.) as a measure to assess the performance and maximizing shareholders' value. In the same context, Stewart Co. also formulated another performance 
standard, represented in the market value added (MVA) as an indicator of the external performance indicators of the enterprise, as well as a measure of the enterprise's ability to generate wealth by increasing the market value of equity (Abu Wadi \& Saqfal-Hait, 2016).

The economic value added is defined as the difference between the company's net operation profits and the cost of capital. The added market value represents the difference between the market value and the book value of equity. Many researchers have pointed out that economic value added is superior to the traditional accounting measuresin terms of their apparent impact on shareholders' value (Wet, 2005). The economic value added is based on converting the accounting profit into an economic profit, which create a close correlation between the economic value added of the enterprise and the market value of the share, thus maximizing the owner's wealth (al-Sheikh, 2012).

Based on the above, this study seeks to examine the impact of economic value added, market value added and traditional accounting measures in maximizing shareholders' value in Jordanian commercial banks, in an effort to fill the shortfall in accounting literature and to determine the most far-reaching and significant measure on shareholders' value.

\section{The Research Problem}

The problem with the study is represented in the numerous criticisms against of the conventional accounting standards, particularly in terms of their inability to reflect the real value of the company. Although there are a variety of accounting standards and indicators, but they remain unable to explain the change in shareholders' value (Vijayalakshmi, 2014).

The traditional accounting standards may also be one of the reasons for weak corporate performance if used to measure shareholders' earnings or value (AbdulRazzaq et al., 2008), where shareholders generally suffer from the lack of an appropriate performance measurement tool that can help them to assess the returns on their investments in the shares of the company.

With the shift towards economic metrics of performance, it becomes necessary to know whether these measures are able to better explain the change in shareholders' value than traditional ones, and to know the extent of how far they correlate and holistic impact on that wealth.

Based on the above, it can be said that this study seeks to answer the following questions:

1) What is the impact of economic value added on maximizing the shareholders' value in the Jordanian commercial banks?

2) What is the impact of market value added on maximizing the shareholders' value in the Jordanian commercial banks?

3) What is the impact of conventional accounting standards on maximizing the shareholders' value in the Jordanian commercial banks?

\section{The Objectives of the Study}

This study mainly aims to test the impact of economic value added, market value added and traditional accounting standards on maximizing the shareholders' value' value in the Jordanian commercial banks. The objectives of the study can be detailed as follows:

1) To know the impact of economic value added on maximizing the shareholders' value in Jordanian commercial banks.

2) To know the effect of market added value on maximizing the shareholders' value in Jordanian commercial banks.

3) To know the impact of traditional accounting standards on maximizing the shareholders' value in the Jordanian commercial banks.

\section{The Hypotheses of the Study}

HO 1: There is no statistically significant effect of economic value added (EVA) on maximizing the shareholders' value in the Jordanian commercial banks.

HO 2: There is no statistically significant effect of market value added (MVA) on maximizing the shareholders' value in the Jordanian commercial banks.

HO 3: There is no statistically significant impact of the Return on Assets (ROA) on maximizing the shareholders' value in the Jordanian commercial banks. 
HO 4: There is no statistically significant impact of the rate of Return on Equity (ROE) on maximizing the shareholders' value in the Jordanian commercial banks.

HO 5: There is no statistically significant impact of Earning Per share (EPS) on maximizing the shareholders' value in the Jordanian commercial banks.

\section{Previous Studies}

Several previous studies examined the relationship between economic standards, traditional accounting standards and the shareholders' value.

A study conducted by (Panigrahi, 2017) tested performance measurement tools and their relationship to the shareholders' value on a sample of Malaysian public shareholding construction companies during the period 2003-2012. The stud indicated that many Malaysian companies still use traditional measurements despite criticism against them. The study also noted that the traditional accounting standards and economic metrics do not reflect the real company's value. The study concluded that the value of equities is deemed an indicator in the performance measures. The results of the study pointed to the important role of stock profitability, economic value added and dividend distribution. The study found that there was an inverse correlation between the market value added and the value of equity, which contradicted the theory that indicates to the increase in equity value is growing with the increase in market value of the shares.

(Bognárová, 2017) study pointed out that the economic value added (EVA) is one of the most important modern performance measures, and that the main difference between EVA and the traditional accounting standards is that EVA includes the costs of financing through debt or through ownership, as well as it mitigate somewhat the accounting distortions. The study also noted that the economic value added and the added market value provided a more accurate assessment of the financial performance of the company.The study conducted a case study to analyze the use of economic value added in a sample of Slovak companies during the period 2010-2015. The study concluded that modern performance measures; such as economic value added outweighs the traditional performance standards; such as profits and the share profitability in interpreting changes in market value added.

The study conducted by (Abu Wadi \& Saqf al-Hait, 2016) aimed to analyze traditional accounting performance indicators (the rate of return on equity) and modern performance assessment indicators (economic value added) of the Jordanian commercial banks during the period 2000-2013, in addition to identifying the indications of these standards as indicators of performance assessment and their use to interpret the market added value. The results of the study showed that there is a statistically significant direct relation between the rate of return on equity and the market value added of Jordanian banks, as well as between the economic value added and the market value added of Jordanian banks, but the economic value added gave better results than the indicator of return on equity.

The study of (Fayed \& Dubey, 2016) compared three sets of performance measures, namely: the traditional accounting measures, market-based measures and value-based metrics, with a particular focus on economic value added. The study was based on a sample of public shareholding companies listed on the UAE stock exchanges during the period 2008-2013. The study concluded that the economic value added, as well as the value-based metrics did not provide much additional information content, while the multiplier of market value ratio to the book value provided arelatively important information outweighed other metrics.

The study of (Saifi \& Bin Amara, 2015) aimed to determine the extent to which the value-added indicator could measure the financial performance by determining extent of its ability to interpret dividends, compared to the traditional accounting indicators of financial performance, together with the market value added indicator. The study is based on a sample of companies listed in the CAC40 indicator of Paris Stock Exchange during the period 2008-2013. The results of the study showed superiority of market value added over other performance indicators in the interpretation of dividends, including the economic value added indicator.

The study of (Panigrahi et al., 2014) examined the importance of the economic value-added to maximize the shareholders' value. The study noted that the economic Value added (EVA) is a value-based tool in assessing performance and reflects the problems of conflict between managers and shareholders. Using a sample of 28 public shareholding companies listed on the Malaysia Stock Exchange during the period from 2003 to 2012, the study found that there was a positive and significant correlation between the economic added value and the maximization of shareholders' value. The results also showed that the higher the economic value added, the higher the shareholders' value.

The study of (al-Muhtadi, 2014) aimed to analyze the economic value added and traditional measurements (including the earning per share (EPS), return on investment, operational cash flow and return on equity) and its 
use in measuring the change in the market value of the Bank of Palestine stock prices during the period 2004-2012. The study found that the market value of the Bank of Palestine shares was strongly correlated with traditional performance assessment measures combined and better than if it was alone in measuring the change in the market value of the share. The study also found that the economic value added was the best measure in measuring the change in the market value of the Bank of Palestine shares.

The study conducted by (Bhasin \& Shaikh, 2013) examined the value-creation strategies of a sample of Indian companies by analyzing whether the economic value added (EVA) represents the market value of these companies compared with the traditional performance measures. The study analyzed the economic value added and the traditional performance measures; such as the earning per share, the return on capital employed, and the return on the net value by using trend analysis and regression analysis. The results of the study showed that there was no strong evidence to support the fact that the economic value added was overweighs traditional performance measures in its correlation to the market value added.

The study of (Kaddoumi et al., 2012) analyzed the relationship between the economic value added (EVA) and the traditional accounting measures and between the market value of shares. The traditional accounting measures included return on assets (ROA), Return on equity (ROE), operational cash flow, earning per share, dividends per share (DPS) and book value. The study relied on a sample of 31 public shareholding companies listed on the Amman Stock Exchange. The study found that the market value of equities is more correlated to the traditional performance measures than to economic value added, and that the traditional performance standards were capable of interpreting a larger amount of change in market value of shares.

A study conducted by (Kootanaee et al., 2012) comparedthe performance measures to find out the best measure of the enterprise performance, relying on a sample of Iranian companies listed on the Tehran Stock Exchange. It examined the relationship between the profitability indicator, operational cash flow, the economic value added and the market value of shares. The study found that the earning per share indicator and the value-added indicator have strong correlation with the market value of shares.

The aim of the study conducted by (Vijayakumar, 2011) was to assess whether the economic value added (EVA) had a significant explanatory capability relying on a sample of 20 automobile companies in India. To find out the factors that have greater contribution to maximizing shareholder returns, the study used the Factor Analysis method to identify the most influential factors in the economic value added, out of eight variables: earning per share (EPS), sales, profit after tax, market value, market value added, return on sales, return on assets, and return on capital employed. The results of the study showed that, of the eight variables, three important factors can be extracted, which explain $69.9 \%$ of the change in economic value added. The results also showed that after-tax sales and profits have the strongest relationship with the added economic value.

\section{The Theoretical Aspect of the Study}

\subsection{Traditional Accounting Standards}

There are many traditional accounting standards used in evaluating performance, of which the most significant are:

\subsubsection{Earnings Per Share (EPS)}

EPS is one of the important indicators used by current and potential investors to assess the profitability of the company. It aims to judge the company's efficiency in exploiting the shareholders' funds and its success in maximizing the wealth of owners. This indicator can also be used to assess the prices of ordinary shares and to assess the ability of the company to cover and pay dividends. Earnings per share is calculated by dividing the company's annual net profits by the number of shares issued (Lulu, 2016).

\subsubsection{Return on Assets (ROA)}

It is one of the most common performance indicators. It measures the efficiency of a company's management in using assets to generate profits. This indicator is of great importance among researchers because of the many advantages that are available, the most important of which is that it measures the overall performance of the organization, provides information about the returns of the assets of the organization, provides a benchmark for comparing the present and past performance of the organization and between the performance of the organization and other organizations in the same industry (Suweis, 2010). The rate of return on assets can be calculated by dividing the net profit on total assets (Mreiziq, 2014).

\subsubsection{Return on Equity (ROE)}

This measure is a commonly financial performance indicator being used. It expresses the company's ability to 
generate profits on owners' funds (Kiwan, 2010), as it measures the return on each dinar invested by the shareholders. The rate of return on equity can be calculated by dividing net profit on total equity.

\subsection{The Most Important Defects and Criticisms Against Traditional Accounting Standards}

Despite of the importance of traditional accounting standards, and their broad use by accountants, practitioners, local financial professionals and other groups, these indicators suffer from many disadvantages which can be summarized as follows (Shibli, 2009):

1) The inability of traditional accounting standards to determine the true economic value of the owners' wealth, which is reflected in the market value of the shares.

2) Ignoring the cost of financing by equity or shares in the accounting profit account, because accounting profit takes into account the cost by debt financing only and ignores the cost of financing by ownership.

3) Reliance on accounting information prepared under the historical cost principle, which reduces the ability of that information to reflect the real value of such information or changes that may occur.

4) Weakness of its ability to detect failures and bankruptcy that the organization may be exposed to.

5) Its inability to assist current and potential investors in taking their prudent investment decisions.

Based on the above, the need for new assessment indicators that are capable of overcoming the disadvantages of traditional accounting standards has emerged, which can be dependable to provide more appropriate and useful additional information to decision maker. This led to the emergence of new indicators, the most important of which are the economic value added and market value added.

\subsection{Economic Value Added and Market Value Added}

\subsubsection{Economic Value Added}

Many researchers believe that in order for the organization to be able to create wealth, it must be able to make profits greater than the cost of the organization's capital. This led to the emergence of new performance indicators, the most important of which is the Economic Value Added (EVA) developed by a US consulting firm, (Stern and Stewart Co.), as a measure of performance and maximizing shareholders' value. This measure is considered to be one of the best performance measures compared to the traditional accounting standards and it is the best indicator in measuring the extent of the organization ability to create shareholders' wealth (Saifi \& Amara, 2015).

The idea of using economic value added stems from the fact that shareholders must make a return that compensates the risks to which they are exposed. That is, the return on ownership must be at least equal to the return on investments with similar risks in the stock market. This means that wealth arises when a company achieves revenues greater than the cost of investment or the cost of business management. Thus, the concept of value creation for shareholders is achieved when the company's returns on its capital are greater than the opportunity cost. In addition to the above, unlike traditional metrics; such as return on investment (ROI) and return on equity (ROE), which discourage managers to make decisions that correspond to the objectives of the company and maximize the shareholders' value. The rewards based on economic value added lead to link the objectives of staff and managers to the objectives of the entire company (Yahya et al., 2009).

The economic value added indicator is the developed form of the concept of remaining profits. The difference between the two concepts lies in the purpose of use; where the remaining profits indicator is used to serve managers as a tool to assess the internal performance of the Organization and its various units, while the economic value added indicator is used to serve shareholders, as well as a communication tool used by managers to pass information to shareholders on the performance of the organization. The remaining profits take into account the cost of internal opportunity, while the economic value added depends in its calculationon the cost of the invested capital (from debt or ownership) (Sharqawi, 2006).

The economic value added is defined as a measure of financial performance that accurately reflects the company's economic performance (Stewart, 1991). The measure of the added economic value is a measure that enables managers to know if they are making appropriate return or not. It is a value-based financial performance metric, an investment decision-making tool, and a performance measurement that reflects the absolute shareholders ' value. It is the product of the additional return achieved on investment and on the capital invested. The economic value added is calculated by subtracting the cost of alternative opportunity of the invested capital for the project, from the net operating profit, thus it is an estimate of the real economic profit of the organization (Yahya et al., 2009). 
(Stewart, 1994) pointed out that economic value added overweighs the other performance measures in four substantial aspects (Bhasin \& Shaikh, 2013), namely:

- It is closer to the real cash flow of the organization.

- It is easy to calculate and understand.

- Has a greater relationship with the market value of the organization.

- Can be applied on employees' benefits and rewards leading to the harmonization of the management and shareholders' interests, and thus reduces the contradiction between them.

The model of economic value added can be expressed through the following equation (Shil, 2009).

$$
E V A=\text { NOPAT-IC }(\text { WACC })
$$

Where:

EVA: Economic Value added.

NOPAT: Net operation profit before interests and after taxes.

IC: is the invested capital.

WACC: is the weighted average of the cost of capital.

\subsubsection{B- Market Value Added (MVA)}

The added market value is defined as the difference between the company's total market value and the economic capital. The economic capital or invested capital (IC) represents the amount that has been placed in the company and consists mainly of fixed assets plus net working capital. From the investor's point of view, the market value added (MVA) is the best final measure of the company's performance. Although the market value added is calculated at a certain point of time, it can be calculated for several periods for the purpose of determining the difference or change in value added and to know whether there has been improvement or reversal (Bognárová, 2017).

The positive value of the market added value indicates that there is an increase (or addition) of the company's value, while the negative value indicates a decline or decrease in the company's value. If the enterprise has made a return equal to the cost of its capital, then the market value added in this case would be zero, but if the enterprise could achieve revenues higher than the cost of the invested capital, the added market value would be positive. The market value added represents the amount of wealth generated from the capital and reflects the market assessment of the effectiveness of the enterprise's management in the use and control of available resources and the competitive position in the market (Jadoo, 2007).

The market value added can be calculated through the following formula (Panigrahi, 2017):

$\mathrm{MVA}=$ Equity market value - Equity book value

Equity Market Value $=$ No. of outstanding shares $*$ Market Share price

Since the market valueadded reflects investors' expectations of the future revenues that will be acquired by the enterprise, the relationship between market value and economic value added can be determined by looking at the market value added as equal to the total current value of the future economic value added of the company (Bognárová, 2017).

\section{MVA $=$ present value of all Future EVA}

Therefore, the change in the economic value added (EVA) over a certain period of time is highly correlated with the change in market value added, which create a close relationship between the two measurements. Some believe that the measure of economic value added is an internal measure of performance, while the market valueadded measure is deemed an external and comprehensive measure of performance (Kiwan, 2010).

\section{Data and Methodology of the Study}

\subsection{The Study Community and Sample}

The study community consists of all 13 Jordanian commercial banks listed on the Amman stock Exchange at the end of 2017. The study sample was selected by using the comprehensive survey method where the sample has to include all Jordanian commercial banks that are made up of the study community during the period 2010-2016. The annual financial statements of the banks were obtained from the company manual issued by the Amman Stock Exchange during the study period. 


\subsection{Study Form}

This study aims to determine the impact of economic value added, market value added and traditional accounting standards in maximizing the shareholders' value. The acquaintance with the methodologies used in previous studies aimed at testing the impact of economic value added, market value added and traditional accounting standards on the shareholders' value, especially the study conducted by (Panigrahi, 2017), the study of (Bognárová, 2017) and study of (Panigrahi et al., 2014), the standard model for this study can be developed as follows:

$$
\operatorname{CSV}_{i, t}=\beta_{0}+\beta_{1} R O A_{i, t}+\beta_{2} R O E_{i, t}+\beta_{3} E P S_{i, t}+\beta_{5} E V A_{i, t}+\beta_{6} M V A_{i, t}+\varepsilon_{t}
$$

Where:

$\operatorname{CSV}_{i, t}$ is a measure of the shareholders' value in the bank (i) in the period (t).

$R O A_{i, t}$ is the return on assets of the bank (i) in the period (t).

$R O E_{i, t}$ is the return on equity of the bank (i) in the period (t)

$E P S_{i, t}$ is the earning per share of the bank (i) in the period (t)

$E V A_{i, t}$ is the economic value added of the bank (i) in the period (t)

$M V A_{i, t}$ is the market value added of the bank (i) in the period ( $\mathrm{t}$ ).

\subsection{The Operational Definitions of the Study Variables}

\subsubsection{Dependent Variable}

1) Shareholders' value created: this measure is attributed (Rappaport, 1986) which the amount of additional wealth created to the shareholders of the bank. The idea behind this measure is that one of the most important objectives of the companies is to maximize the wealth of the shareholders, thus the company's success in creating valueadded on the shareholders' value is deemed an indicator of its good performance to achieve the primary objective of its existence. The change in shareholders' value can be measures through using the overall return achieved by the company to the shareholders (Powers, 2010). The shareholders' value added can be calculated by the difference between total return on shareholders and the cost of ownership as follows (Panigrahi et al., 2014):

$$
C S V=E M V^{*}(S R-C E)
$$

Where:

CSV: is the shareholders' value added

EMV: is the market value of shares which is calculated through multiplying the number of shares by the market value of per share.

SR: is the return on shareholders which is measured through the return on the retention period and includes the return on distributions plus profit or capital loss.

CE: is the cost of ownership which can be calculated through the capital asset pricing model (CAPM).

\subsubsection{Independent Variables}

1) Rate of Return on Asset (ROA): it is the net annual profits of the bank divided by the total assets (Mreiziq, 2014)

$$
\mathrm{ROA}=\text { net income } / \text { total assets }
$$

2) Rate of Return on Equity (ROE): it is the net annual profits of the bank divided by the total equity (Chary \& Mohanty, 2009)

$$
\mathrm{ROE}=\text { net income/ total equity }
$$

3) Earning per Share (EPS) : it is the net annual profits of the bank divided on the number of shares issued (Lulu, 2016)

$$
\text { EPS }=\text { net income/ number of shares }
$$

4) Economic Value Added (EVA): it can be calculated by calculating the difference between net operation profits before interest and after taxes and between the cost of capital invested as in the following equation (Shil, 2009):

$$
\text { EVA }=\text { NOPAT-IC }(\text { WACC) }
$$

where NOPAT is a net operation profits before interest and after taxes, IC is the invested capital, and WACC is 
the weighted average of the cost of the bank's capital.

5) Market Value added (MVA): it represents the amount of wealth generated from the capital. MVA can be calculated by the following equation (Panigrahi, 2017)

$$
\mathrm{MVA}=\mathrm{EMV}-\mathrm{EBV}
$$

Where

EMV is the market value of shares;

EBV is the book value of shares.

\section{Results of Statistical Analysis}

This section examines the descriptive statistics of study variables and the results of regression analysis to determine the impact of economic value added, market value added and traditional accounting standards on the shareholders' value in the Jordanian commercial banks during the period 2010-2016.

\subsection{Descriptive Statistics}

Table 1 shows the descriptive statistics of the study variables and, through this table, the following can be noted:

Table 1. Descriptive statistics of study variables during the period 2010-2016

\begin{tabular}{lcccccc}
\hline & $\boldsymbol{C S V}$ & $\boldsymbol{R O A}$ & $\boldsymbol{R O E}$ & $\boldsymbol{E P S}$ & $\boldsymbol{E V A}$ & MVA \\
\hline Mean & -396838 & 1.151 & 8.0234 & 0.26126 & 6341649 & 130414360 \\
Median & -293720 & 1.1378 & 8.0058 & 0.26055 & 1529243 & 11532510 \\
Maximum & 1033377 & 1.5146 & 12.4913 & 0.42525 & 25000298 & 229016645 \\
Minimum & -2557064 & 0.6726 & 5.6208 & 0.1578 & -6962348 & 38174311 \\
Std. Dev. & 1354126 & 0.1562 & 0.9704 & 0.0414 & 11401412 & 49725128 \\
Skewness & -0.7575 & -0.1325 & 0.1649 & 0.9069 & 0.6299 & 1.3811 \\
Kurtosis & -2.304 & 2.581 & 2.662 & 2.3350 & -0.7354 & 2.7350 \\
Jarque-Bera & 3.238 & 0.826 & 0.529 & 0.628 & 3.825 & 1.852 \\
Probability & 0.215 & 0.582 & 0.766 & 0.656 & 0.154 & 0.413 \\
Observations & 104 & 104 & 104 & 104 & 104 & 104 \\
Cross sections & 13 & 13 & 13 & 13 & 13 & 13 \\
\hline
\end{tabular}

\section{- Creating Shareholders' Value (CVS)}

The average of CVS of banks in the sample study during the period (2010-2016) was negative, approximately (-397 thousand JDs); i.e. the Jordanian commercial banks were unable to create add value to the wealth of their shareholders, which reflects the poor performance of those banks in their ability to maximize the shareholders' value. The shareholders' value added ranged from(-2.56 million JDs to 1.03 million JDs), with a standard deviation reached 1.35 million JDs. This reflects a significant difference in the ability of Jordanian commercial banks to add value to their shareholders.

\section{- Return on Assets (ROA)}

The average rate of return on assets of the banks in the study sampleduring the period (2010-2016) was about $1.15 \%$, which ranged from $0.67 \%$ to $1.51 \%$, with a standard deviation of $0.16 \%$. The previous values indicate the ability of Jordanian commercial banks to achieve a positive rate of return on assets during the study period, with a relative convergence of banks in terms of the rate of return on assets.

\section{- Return on Equity (ROE)}

The average rate of return on equity of the banks in the sample during the study period was $(8.02 \%)$, which ranged from $5.62 \%$ to $12.5 \%$, with a standard deviation of $0.97 \%$. This reflects the ability of Jordanian commercial banks to achieve a positive rate of return on shareholders' funds during the study period, indicating a relative convergence between the banks in terms of rate of return on equity.

\section{- Earnings per Share (EPS)}

The average of earnings per share of the banks included in the sample during the study period was about 0.26 JDs per share. The earnings per share ranged from $0.16 \mathrm{JD} /$ share to $0.43 \mathrm{JD} / \mathrm{share}$, with a standard deviation of 4 piasters in average, which indicates the ability of commercial banks to create positive profits for equities, and 
shows a convergence of the level of EPS in the Jordanian commercial banks.

\section{- Economic Value Added (EVA)}

The average of economic value added of Jordanian commercial banks during the period of study was positive, approximately 6.34 million JDs, reflecting the ability of Jordanian commercial banks to create positive economic value added during the study period. The economic value added ranged from (-6.96 million JDs to 25.00 million JDs), with a standard deviation of 11.4 million JDs, reflecting a clear disparity and difference among the Jordanian commercial banks in achieving economic value added during the study period.

\section{- Market Value Added (MVA)}

The average of MVA of the Jordanian commercial banks during the study period was positive, in the range of 130 million JDs. This reflects the ability of Jordanian commercial banks to create positive market value added during the study period. The added market value ranged from 38.2 million JDs to 229.0 million JDs, with a standard deviation of 49.7 million JDs, reflecting a clear disparity and divergence among Jordanian commercial banks in achieving market value added during the study period.

\section{- Other statistics}

(Skewness and Kurtosis) and (Jarque-Bera) statistics show that the distribution of dependent and independent variables is normal. The number of views was 104 time, reflecting 13 bank statements for 7 years (2010-2016).

\subsection{Results of Regression Analysis}

This section aims to test the impact of market value added, economic value added and traditional accounting measures on the shareholders' value in the Jordanian commercial banks during the study period 2010-2016. The common regression analysis method (Pooled Data regression) will be used considering to its suitability for the nature of the data used in the study, as this method is used where the data include a time series and cross-sectoral.

Table 2 shows the results of the regression analysis of testing the impact of market value added, economic value added and traditional accounting standards on the shareholders' value in the Jordanian commercial banks.

Table 2. Regression analysis results (*) of testing the impact of market value added, economic value added and traditional accounting standards on the shareholders' value in the Jordanian commercial banks

\begin{tabular}{|c|c|c|}
\hline \multicolumn{3}{|c|}{$C S V_{i, t}=\beta_{0}+\beta_{1} R O A_{i, t}+\beta_{2} R O E_{i, t}+\beta_{3} E P S_{i, t}+\beta_{5} E V A_{i, t}+\beta_{6} M V A_{i, t}+\varepsilon_{t}$} \\
\hline & Variable & Coefficient \\
\hline Constant & & $1.8 \mathrm{E}+07(7.673)^{* * *}$ \\
\hline ROA & & $2.1 \mathrm{E}+07(9.077)^{* * *}$ \\
\hline$R O E$ & & $187248(0.599)$ \\
\hline$E P S$ & & $1.2 \mathrm{E}+07(1.142)$ \\
\hline$E V A$ & & $0.29467(14.846)^{* * *}$ \\
\hline$M V A$ & & $-0.00224(-0.993)$ \\
\hline \multicolumn{3}{|c|}{ Regression Statistics } \\
\hline$R$-squared & & 0.8623 \\
\hline Adjusted $R$-squared & & 0.8454 \\
\hline Durbin-Watson stat & & 1.8788 \\
\hline F-statistic & & 125.2694 \\
\hline $\operatorname{Prob}(F$-statistic $)$ & & 0.0000 \\
\hline
\end{tabular}

(*) Method: Pooled EGLS (Cross-section weights);

- Values in parenthesis denote t-statistic.

- ***, **, and * denotes significance at the $1 \%, 5 \%$ and $10 \%$ respectively.

- White diagonal standard errors \& covariance (d.f. corrected).

It is noted in the above table that coefficient of Return on Assets has a positive and statistically significant impact at statistical significance level $1 \%$, which means that the improvement of the return on assets contributes in maximizing the shareholders' value in the Jordanian commercial banks.

The remaining accounting metric used, including return on equity, and earning per share have no statistically significant impact on the shareholders' value in the Jordanian commercial banks. 
With respect to the measure of economic value added, the results affirm that it has an important positive statistical impact on the shareholders' value in the Jordanian commercial banks, which means which means that the improvement in economic value added contributes to maximizing shareholders' value. This conclusion confirms that the economic value added measure has a significant role in interpreting the change in the prices of commercial bank shares, and thus, the importance of this measure in the assessment of shares and forecasting thereof in the future. This result is also in consistent with the findings of the study conducted by (Panigrahi, 2017) and the study of (Panigrahi et al., 2014). The results of this study contravene with the conclusions of (Bhasin \& Shaikh, 2013) and (Kaddoumi et al., 2012) studies.

The market value added (MVA) measure did not have any statistically significant impact on the shareholders' value in the Jordanian commercial banks. it contravenes the findings of most previous studies in this area; such as the study of (Saifi \& Ben Amara, 2015), which emphasized the importance of the market value added measure. it also violates the results of the study of (Panigrahi, 2017), which found a reverse correlation between the market value added and equity value. The reason may be due to the lack of market value added impact linked to the efficiency of pricing in Amman Stock Exchange in general, where the prices of the banks shares listed in the Stock Exchange do not reflect the fair and real assessment of such shares. There are many banks shares are considered to be priced below their fair value, as well as the market value of shares declined during the study period without any basic indicators justifying such decline.

The adjusted explanatory force (adj. R2) for the independent variables is $84.5 \%$, which is relatively high and reflects the explanatory ability of independent variables to interpret the change in the dependent variable. The statistical value (Durbin-Watson) of the sequential correlation of the values of the dependent variable is approximately 1.88 , which is close to (2), which means that there is no sequential correlation problem in the values of the dependent variables and thus confirms the correctness and suitability of the study data for the regression method. Finally the $(\mathrm{F})$ value and its importance indicates (Prop. F-statistic) to the solvency of the study form (goodness of fit).

\section{Findings and Recommendations}

This study aims to test the impact of economic value added, market value added and traditional accounting standards on the shareholders' value in the Jordanian commercial banks during the period 2010-2016.

The results showed that Jordanian commercial banks were unable to create positive value added on the shareholders' value during the study period. The traditional accounting standards have shown that the profitability of Jordanian commercial banks is generally good, as they could achieve a positive return on assets and equity during the study period, and the EPS was good too. The economic value added (EVA) and the market value added (MVA) were positive during the study period, reflecting the ability of Jordanian commercial banks to create positive economic and market value added.

The results of the regression analysis showed that only two measurements had an impact on the shareholders' value in Jordanian commercial banks. The rate of return on assets (ROA) and the economic value added (EVA) had a positive and statistically significant impact in maximizing the shareholders' value, while the rest of the traditional accounting standards or the market value added did not have any significant impact on the shareholders' value.

Relying on the results obtained, it can be argued that the traditional accounting measures (specifically the rate of return on assets) continue to be an important input for stock assessment, and are deemed one of the main indicators on which the Jordanian commercial bank stock prices are moving, reflecting its important role also to maximize the shareholders' value.

Modern performance assessment measures (specifically economic value added) have an important role in maximizing shareholders' value, as they contain important information and signals for shareholders and investors in the financial market, and are therefore directly reflected in stock prices.

The study recommends that the performance assessment of banks should be based on two criteria, namely, the rate of return on assets and the economic value added. It also recommends that investors and financial analysts should build stock assessment models using these measurements.

\section{References}

Abu Wadi, R., Saqif al-Hait, \& Naheil. (2016). The value of economic value added as a supplement tool to assess the Jordanian commercial banks performance. An- Najah University Journal for researches (Humanitarian Sciences), 30(12), 2493-2520. 
Alkhalialeh, M. (2004). Earnings Based and Cash Flow Based Performance Measures and Their Association with Stock Return Variation: An Empirical Study on Companies Listed in Amman Stock Exchange. Arab Journal of Administrative Sciences, 11(2), 183-204.

Al-Muhtadi, G. (2014). The use of traditional financial performance indicators and economic value to measure changes in market value of shares, Bank of Palestine case.Unpublished Master Thesis, Islamic University, Gaza.

Al-Sheikh, E. (2012). Comparative Study on The Effect of Using Traditional Measures of Performance and the Measure of Economic Value Added on The Stock Prices. Arab Journal of Administrative Sciences, 9(2), 207-238.

Bhasin, M., \& Shaikh, J. (2013). Economic value added and shareholders' wealth creation: The portrait of a developing Asian country. International Journal of Managerial and Financial Accounting, 5(2), 107-137. https://doi.org/10.1504/IJMFA.2013.053208

Bognárová, K. (2017). Analysis of The Relationship Between Economic Value Added and Market Value Added. Challenges of the Knowledge Society, Finance and Accounting, 7, 793-796

Chary, L., \& Mohanty, R. (2009). Understanding Value Creation: The Shareholder value perspective. LBS Journal of Management \& Research, 7(1-2), 12-26.

Fayed, A., \& Dubey, S. (2016). An Empirical Study of Impact of EVA Momentum on the Shareholders Value Creation as Compared to Traditional Financial Performance Measures - With Special Reference to the UAE. International Journal of Economics and Finance, 8(5), 23-38. https://doi.org/10.5539/ijef.v8n5p23

Jado, S. K. (2007). Analytical study of the effectiveness of the application of value-based management to maximize the value of equity in economic units, a field study. Scientific Journal of Economics and Commerce, $1(2)$.

Kaddoumi, T., Kilani, Q., \& Amarneh, A. (2012). Whichever is more able to interpret the change in the market values of equities, is it the economic value added or traditional performance criteria. Jordan Journal of Applied Sciences, 14(1), 1-18.

Kiwan, R. (2010). The Effect of Managers' Entry Structure on Economic Value Added in Egyptian Establishments, Applied Study. Journal of Commercial Researches, 32(1).

Kootanaee, H., Kootanaee, A., Talari, H., \& Babu, K. (2012). A Comparison of Performance Measures for Finding the Best Measure of Business Entity Performance: Source from the Tehran Stock Exchange. Journal of Finance and Investment Analysis, 1(4,3).

Lulu, S. (2016). The ability of the economic value added index versus the traditional performance indicators to explain the change in the market value of the shares, an applied study of companies listed on the Palestine Stock Exchange. Unpublished Master Thesis, Islamic University, Gaza .

Mreiziq, R. (2014). The Effect of Profitability Ratios and Liquidity Ratio on the Market Value of the priced organization, a study of a sample of listed institutions in Qatar Stock Exchange. unpublished Master Thesis, University QasidiMerdah - Ouargla, Algeria .

Othman, I., Ching, P., \& Ghazali, A. (2012). The relationship between Economic Value Added and Malaysian stock market performance. Paper presented at the International Conference on Innovation Management and Technology Research (ICIMTR). https://doi.org/10.1109/ICIMTR.2012.6236416

Panigrahi, S. (2017). Economic Value Added and Traditional Accounting Measures for Shareholder's Wealth Creation. Asian Journal of Accounting and Governance, 8, 125-136. https://doi.org/10.17576/AJAG-2017-08-11

Panigrahi, S., Zainuddin, Y., \& AND Azizan, A. (2014). Comparing Traditional and Economic Performance Measures for Creating Shareholder's Value: A Perspective from Malaysia. International Journal of Academic Research in Accounting, Finance and Management Sciences, 4(4), 280-289. https://doi.org/10.6007/IJARAFMS/v4-i4/1345

Powers, G. T. (2010). Economic Profitability of Regulated vs. Unregulated Industries. Simon Fraser University.

Rappaport, A. (1986). Creating shareholder value: the new standard for business performance (Vol. 22). Free press New York.

Saifi, H., \& Amarah, N. (2015). Measurement of financial performance using the economic value added indicator: 
A case study of the institutions listed in the CAC40 index during the period 2008-2013. Al-Bahith Journal, (15), 179-190.

Saifi, H., \& Amarah, N. (2015). Measuring the financial performance using the economic value added indicator, an analytical study on the public shareholding industry in Jordan. Afaq Jouranl, Economic Magazine, 27(106).

Shibli, A. M. (2009). The use of economic value added in assessing the financial and operational performance in economic units. Journal of Economics, (23), 135-158.

Swis, H. (2010). A Study and analysis of indicators of enterprise assessment performance measurementfrom the perspective of value creation. Scholar Magazine, (7).

Vijayakumar, A. (2011). Economic Value Added (EVA) and Shareholders Wealth Creation: A Factor Analytic Approach. Research Journal of Finance and Accounting, 2(12), 22-38.

Vijayalakshmi, R. (2014). Shareholders wealth creation in select BSE 100 listed companies. International Journal of Research in Finance and Marketing, 4(8), 1-10.

Wet, J. (2005). EVA versus traditional accounting measures of performance as drivers of shareholder value - A comparative analysis. Meditari Accountancy Research, $13(2), \quad$ 16. https://doi.org/10.1108/10222529200500009

Yahaya, N., Kila, S., \& Mahmood, W. (2009). Creating Wealth for Shareholders: Evaluating the Performance of the Malaysia Property Companies. Munich Personal RePEc Archive, MPRA Paper No. 14602, posted 13. April 2009.

\section{Copyrights}

Copyright for this article is retained by the author(s), with first publication rights granted to the journal.

This is an open-access article distributed under the terms and conditions of the Creative Commons Attribution license (http://creativecommons.org/licenses/by/4.0/). 